\title{
Taking Stock and Looking Ahead: Drama Pedagogy as a Gateway to a Performative Teaching and Learning Culture
}

\author{
Manfred Schewe
}

\begin{abstract}
This overview article initially focuses on early connections between dramatic art, teaching, learning, and living, followed by a brief account of how Great Britain took on a pioneering role with regard to the establishment of drama as a school subject, method and educational subdiscipline. It then focuses on how drama pedagogy in foreign language teaching and learning has developed as a specific field of research and practice since the 1970s, acknowledging the important contributions to the field made by scholars and practitioners from outside Great Britain. An overview of current practice in the field is given by presenting different (small-scale and large-scale) forms of staging language, literature and culture. The article concludes by proposing a model for a „Performative Fremdsprachendidaktik" (Performative Foreign Languages Didactics) and by arguing that in the future "performative" be used as an umbrella term to describe forms of foreign language teaching and learning that derive from the performing arts.
\end{abstract}

\section{Early connections between dramatic art and teaching, learning, and living}

The metaphor of the world as a stage (theatrum mundi), tends to be associated in particular with the Spanish Baroque poet, Calderón de la Barca. In the first part of his famous 'sacramental play', El gran teatro del mundo (1636) God, as 'The Author', speaks of the world as a wonderful but in the end short-lived theatre, in which the drama of human life is acted out. ${ }^{1}$ The 'World' actually becomes a character in the play 'The Master' wishes to see performed - the play of human life.

\footnotetext{
1 The idea of the world as a stage had already been introduced in Shakespeare's play As you like it as far back as 1599: "All the world's a stage/And all the men and women, merely players/They have their exits and their entrances/And one man in his time plays many parts" (Shakespeare, 2007: 227).
} 
The idea of life as a play as well as the idea of understanding life better through play, has existed for quite some time in the history of European culture. Since ancient times, dramatic art has raised fundamental questions about both the limits and the possibilities of human existence. In addition, there are also early indications of the roles dramatic art can play in the field of education, in order to help individuals to come to a better understanding of what life is about and to develop abilities and skills which might be of value in the course of their education and personal development.

Philip Coggin (1956) illustrates this in his historical survey which ranges from Ancient Greece to the present day. The use of drama in educating children, for example, goes back to Plato (427-347 BC) who believed that children should learn in a playful way and be allowed to blossom by having as few constraints as possible on them (Coggin 1956:7ff). Coggin also refers to Quintilian (35-97 approx.) who regarded actors as exemplars of the art of delivering speech (ibid: 23f.). In the early Middle Ages, Benedictine monks began to accompany their singing of sacred hymns with gestures and movements, the first steps towards the emergence of liturgical plays. From that time onwards forms of drama-based education became increasingly popular (ibid: 45f.). Coggin emphasises the vital importance of mystery and morality plays in educating people at a time when access to books and learning was reserved for the privileged classes of medieval society (ibid: 52 ).

According to Coggin the increasing use of drama-related activities in European schools towards the second half of the $16^{\text {th }}$ century, can be explained by the influence of humanist ideals of education (ibid: 58). From 1560 onwards, for instance, the performance of a play in Latin and English had become an annual event at the Westminster school; it was felt to provide a good training in appropriate behaviour ("proper action") and to help to polish the students' pronunciation skills. ${ }^{2}$ While he mainly focuses on England, Coggin also occasionally refers to developments outside his home country when, for example, he mentions Goethe's father and how he overcame his sceptical attitude towards theatre by eventually coming to the conclusion that participation in school plays does, in fact, have a beneficial effect:

We know that his father disapproved very strongly of the theatre, until he found that it was teaching young Goethe to speak French faster than any tutor. (Coggin 1956:171)

It seems that this attitude was also shared by committed language teachers at English schools from the mid- $19^{\text {th }}$ century onwards:

As in the Renaissance, the mid-century schoolmasters first adopted drama as an aid to language study. French and German were beginning to enter

\footnotetext{
2 Participating in the staging of a school play in Latin in order to improve linguistic competence seems to have been a very widespread practice at this time. In 1667, for instance, students of the 'Klosterschule Einsiedeln' in Switzerland were performing the play 'Incendium Londini'. From today's perspective, this is a very noteworthy example of introducing students to 'current affairs', or recent developments in another country (Federer, 2007: 89).
} 
the curriculum, and though they were often taught as dead languages, the more enlightened masters treated them as living, and promoted the oral aspect of their teaching by stage performance. (196)

\section{Drama as a school subject, method and educational sub-discipline: the pioneering role of Great Britain}

In his survey, Coggin shows how, in the climate of pedagogical reform in the early $20^{\text {th }}$ century, the growth in theatre-orientated projects in schools had been complemented by attempts to incorporate drama-related learning activities into the school curriculum. ${ }^{3}$ Teachers became more aware of how the potential of drama for stimulating learning could be exploited in teaching different subjects, including English. In 1911, for example, Dr. Rouse, a teacher in the Perse Grammar School in Cambridge, wrote:

Acting is one of the most potent means of learning. Thought, word and act linked together make an impression such as nothing else can make. In this direction lies the salvation of our schools. We all know how dull a text-book is; a history of English, a manual of grammar, even chemistry books are sometimes dull. But if the teacher uses his book as a suggestion, makes his history a story, sets his pupils to act it, in make-believe, before they know what they are doing, they are practising English composition and English grammar and learning English history. (Coggin 1956:232)

Gavin Bolton's surveys of the history of British drama pedagogy are widely respected within the scholarly community. In various publications (1993 and 1998 among others), he paid homage to the pioneering spirit of teachers in the $20^{\text {th }}$ century who helped to pave the way for drama as a teaching and learning method across the curriculum, and for the establishment of drama as an independent school subject. He refers, in particular, to the theoretical writings and drama teaching practice of Harriet Finlay-Johnson (1911), Caldwell Henry Cook (1917), Peter Slade (1954), Brian Way (1967) and Dorothy Heathcote (Wagner 1979). However, through his own writings (e.g. 1979 and 1984) Bolton himself contributed enormously to drama gradually becoming established as a school subject, a teaching method for various school subjects as well as a sub-discipline within the field of education at many universities.

Over the course of the last three decades, further contributions have been made and new directions have been outlined by representatives of the next generation(s), including Fleming (1997), O'Neill (1995) and Neelands/Goode (2000).

The web pages of the leading British professional association $\mathrm{Na}$ tional Drama (http://www.nationaldrama.org.uk), which also publishes the Drama Magazine (http://www.nationaldrama.org.uk/nd/index.cfm/

\footnotetext{
${ }^{3}$ In this context, note the influential 'Creative Drama' approach developed in the US (Ward 1930).
} 
drama-magazine/), provide a vivid insight into current initiatives and activities in various drama pedagogical fields of practice and into the related subject debate. The International Drama in Education Association (IDEA http:www.idea-org.net), founded in 1992, hosts international conferences at regular intervals and also has a very informative website. ${ }^{4}$ In order to access general information about the developments in the area of research, the journal Research in Drama Education (RiDE) with a special focus on Applied Theatre and Performance is highly recommended. In this context, the activities of the IDIERI, the International Drama in Education Research Institute (http://idieri2012.org/), should also be of interest, including those which led to Ackroyd's (2006) overview of research methodologies in drama pedagogy. For a first systematic evaluation of research projects in the area of 'Educational Drama and Language Arts', see Wagner (1998), although her survey focuses primarily on first-language acquisition.

Over the next few years, inter-disciplinary comparative research projects with a focus on developments in the area of 'Drama, Theatre and Pedagogy' in different cultures could yield important new insights. An initial step in this direction was made by DICE, an international Comenius Project, which aimed at evaluating the impact of drama-based teaching and learning in a range of different institutional contexts in the 12 participating countries. The acronym DICE stands for Drama Improves Lisbon Key Competences in Education and emphasises the overall very positive results of this study. An insightful summary can be found under http://www.dramanetwork.eu/key_results.html. ${ }^{5}$

\section{Drama Pedagogy in foreign language teaching and learning as a field of research and practice (1970s to the present)}

The aforementioned magazine, Research in Drama Education (RiDE), focused on the special topic of Drama Education and Second Language Learning for the first time in issue 4/2011. In the foreword, the editors, Stinson and Winston, take stock of developments in this field since the late 1970s. However, this stock-taking turns out to be rather insular and unfortunately completely ignores the dynamic developments in non-English speaking countries.

In the 1980s and 90s, communicative concepts of foreign and second language teaching and learning were thriving in Europe and worldwide. Taking heed of this development, advocates of drama in education, practitioners and foreign language teaching specialists become increasingly committed to the building of bridges between their respective disciplines. Important first initiatives came from Britain, and the publication by Kao/O'Neill (1998), highlighted in the

\footnotetext{
${ }^{4}$ For information on this year's international congress in Paris, see: http://www.ideaparis-2013.org

5 Also note Almut Küppers': The DICE Consortium (2010), The DICE has been cast. In: SCENARIO, V, 1, 2011, 107-112
} 
aforementioned periodical, makes an important contribution in this respect. Nevertheless, a more systematic classification and conceptualisation of the new practice- and research area in the 1990s and first decade of the $21^{\text {st }}$ century was developed largely outside Great Britain, mainly in German-speaking countries. It is also pursued by those who are teaching and researching outside these countries but nevertheless actively contributing to the subject debate in German-speaking countries and helping to promote international exchange and dialogue in the area of drama pedagogy. The relevant disciplines in this regard are general pedagogy, British drama and German theatre pedagogy as well as the 'didactic disciplines' associated with the relevant school or university subject. Furthermore, research perspectives from a wider spectrum of other professional disciplines, including educational psychology, neuropsychology, social and individual psychology, psycholinguistics, sociology, anthropology, intelligence and creativity research are also being considered.

Manfred Schewe has produced a study (Fremdsprache inszenieren 1993) ${ }^{6}$ in which, for the first time, a foreign language teacher systematically conducts research into his own teaching over a number of years and makes the academic community aware of the innovative role British drama pedagogy can play within foreign language disciplines. ${ }^{7}$ Schewe's concept of drama-based teaching and learning, which has been developed through a process of 'research in action', and conducted and tested with a variety of target groups (e.g. university students in the foreign language classroom as well as teachers in teacher training and further education courses), is informed by the idea of 'Unterricht als sinnliche Gestaltung' (implying the idea of teaching and learning as a multisensory experience, Chapter II) and of 'Drama als Pädagogische Kunstform' (drama as a pedagogical art form, Chapter III). He differentiates between different phases of the foreign language learning experience (sensitisation, contextualisation and intensification) and, on the basis of both longer teaching units as well as short exercises, shows that drama-based foreign language teaching can, in principle, be applied to the three core areas of a foreign language discipline (i.e. language, literature and culture). He supplies a range of examples, including drama-based exercises which can be used to teach vocabulary, pronunciation and to practise listening and reading comprehension. The volume of collected essays Towards Drama as a Method in the Foreign Language Classroom, edited by Schewe/Shaw and published in the same year represents a first attempt to take stock, from an international perspective, of different forms of process and product-oriented drama-based foreign language teaching. Subsequent years have seen further diversification in this new field of practice and research, initiated by research projects that concentrate on specific sub-areas of the foreign language discipline and include the development of specific theoretical frameworks for drama-based teaching and learning in these areas. This is briefly outlined in the following examples.

\footnotetext{
${ }^{6}$ No hard copies of this publication are available anymore, but the full text can be downloaded from: http://cora.ucc.ie/handle/10468/561

${ }^{7}$ A further step in this regard was taken by Elektra Tselikas (1998).
} 
In the area of language, Susanne Even (2003) presents her Drama Grammatik (drama grammar) approach, based on British drama pedagogy and particularly on Schewe's concept of drama-based teaching and learning. Her studies strive to generate principles and parameters for teaching grammar in the context of German as a Foreign Language, with special emphasis on bridging the gap between theoretical linguistic knowledge and the concrete realization of language. She presents detailed lesson plans, e.g. about word classes (ch. VI) or the subjunctive (ch. VIII), based on four teaching phases (awareness-raising, context-finding, linguistic phase, dramatic play) and illustrates how German as a Foreign Language students can approach foreign language grammar in physical, aesthetic, social, emotional, and cognitive ways. ${ }^{8}$

In the area of culture, Angelika Mayrose-Parovsky (1997) uses techniques (for example duplicating, mirroring, role-play) originating in social and theatre pedagogy, in particular Moreno's psychodrama, to back up her concept of Transkulturelles Sprechhandeln. Bild und Spiel in Deutsch als Fremdsprache in order to encourage 'transcultural action' in the multicultural German as a Foreign Language classroom. This can be regarded as preparation for and sensitisation to real life situations which transcends national, cultural and linguistic boundaries. In keeping with the core tenet of psychodramatic role-play, foreign language sessions are divided into three stages (preparation, enactment and post-enactment reflection) and focus on 'transcultural situations' such as family, profession, gifts, acknowledgements and congratulations. The post-enactment reflections aim at 'transcultural depictions of real-life situations'.

In relation to the area of culture, the collected volume, Body and Language. Intercultural Learning through Drama, edited by Gerd Bräuer (2002), should be mentioned along with the concept of 'an intercultural drama pedagogy for the teaching and learning of English as a foreign language (Kessler 2008; Kessler/Küppers 2009). Central to this is the use of specific teaching methods, or rather of 'dramatic conventions', which are applied to the respective 'dimensions of intercultural competence'. The general objective of classes which are structured in this way is the creation of a 'third space' which mediates between 'One's Own' and the 'Other', a space where, through oscillation between the two poles of 'Other' and 'One's Own' or 'Unknown' and 'Known', something new, something shared is born (Kessler 2008:90). In these aforementioned methodologies literary texts also used as a starting and reference point for language and culture learning.

As far as the area of literature is concerned, it should be remembered that many centuries ago plays - mainly canonical texts - were staged in the non-native language(s) and that there has been a long tradition of school theatre groups and school play performances. In the course of mostly extra-curricular rehearsals and productions, the participants gain lasting learning experiences in relation to language, literature and culture together with enhanced personal development

\footnotetext{
${ }^{8}$ Compare Bryant (2012) for a synthesis of grammar instruction and drama pedagogy based on Even's Dramagrammatik in the area of Second Language Acquisition and German as a Foreign Language.
} 
and significant self awareness as has already been documented. (e.g. Bourke, 1993). There has been increasing documentation over the past two decades of the ways in which the dramatization of literary texts through the application of drama teaching methods can enhance the language acquisition experience in the foreign language classroom in a longer teaching unit'. An example of this is Schewe/Wilms' (1995) adaptation of Alfred Andersch's novel, Sansibar oder der letzte Grund, where the sculpture, 'Der Lesende Klosterschüler' (the reading convent student), by Ernst Barlach serves both as a linking element within the tense plot as well as a focus point for classroom activity. The pupils or university students 'translate' the novel's characters into colours and shapes and position them in relation to each other, transform key scenes into pantomime-like freeze frame, imitate the postures of the novel's characters or craft masks in order to use them in a spontaneous scene improvisation. Meanwhile, there is a wealth of studies on the drama-based method of teaching and learning literature. Worth mentioning here is Brigitte Hahn-Michaelis' publication (2011) on the scene-by-scene interpretation of Lessing's 'Nathan der Weise' (Nathan the Prophet) by a multicultural and multilingual group of students at an Israeli university, or Steffi Retzlaff's (2010) drama pedagogical approach to Reiner Kunze's short story 'Schießbefehl' (Order to Shoot). However, the systematisation of such approaches and their classification in order to form a coherent concept of the drama-based teaching and learning of literature is still to come. Generally speaking, in what applies to all three sub-disciplines is that there is a compelling need for relevant research projects that will procure and produce convincing evidence for the effectiveness of drama-based teaching and learning methods in the next few years.

The increasingly lively subject debate about drama-based teaching and learning led to the founding of the (German-English) online specialist journal, Scenario (http://scenario.ucc.ie), in 2007. This journal is geared towards linguists, language teachers, drama and theatre teachers, professional theatre specialists as well as second and third level educationalists. With its emphasis on the role of drama and theatre in teaching and learning foreign and second languages, as well as their corresponding literature(s) and culture(s), it has opened up a platform for a systematic and continuous discourse and exchange about drama- and theatre pedagogy in the teaching and learning of foreign and second languages (as well as in the areas of Drama and Theatre Studies, Psychodrama, Drama Therapy, Playback, Theatre, and Film). Although, in a certain way, drama and theatre pedagogy contradicts the present trend in the teaching and learning of foreign languages towards language for special purposes, measurable outcomes and cognitive learning, it has in the meantime become a respectable and widely used methodology for the most diverse pedagogical contexts (compare Esselborn 2010:249f). This online journal, which has been accompanied by a printed Scenario book edition since 2012 (Schibri Verlag, Berlin) for the promotion of intercultural dialogue in drama and theatre pedagogy, has been the driving force in the building of bridges between the arts and the field of foreign language teaching and learning over 
the past six years.

Meanwhile, inspired by developments in the area of first language teaching and learning (Scheller 2004, Kunz 2010), various foreign language disciplines are participating in the discussion and exchange of ideas about forms of dramaand theatre-based methods for the teaching and learning of language, literature and culture. The spectrum ranges from theoretically based methodologies such as referred to above, to hands-on tips and suggestions, e.g Dockalova's (2011) description of Loops': A multi-purpose drama technique for the language classroom, or Even's (2011) Multiple Hotseating. ${ }^{9}$

\section{Different forms of staging language, literature and culture}

In order to stake out the by now quite impressively wide-ranging field of practice, it might be helpful to differentiate between small-scale and large-scale forms of drama-based teaching and learning. Performative activities which can be realised within the framework of a single class or a shorter teaching unit (approx. 3- 5 classes) may be defined as small-scale forms.

'Process drama' (Bowell/Heap, 2001), for example, falls into the small-scale category. Students and teachers are involved in challenging performative activities during which both the teachers conducting the class and the students take on and impersonate various roles, i.e. that of actor/protagonist, director and dramatist, as well as spectator. Over the course of the classes or teaching units, there is a continuous output in the shape of tangible creations (e.g. pantomimes, freeze-frame depictions and acoustic collages). This requires the learner to act verbally and non-verbally in the respective preparation, re-enactment and reflection phases, which in turn allow the learner to make use of their linguistic and cultural abilities and knowledge in a variety of ways and also to systematically improve on them.

One talks about large-scale forms when the framework of the everyday classroom activity is expanded. Thus, for example, the staging of a production in a foreign language is a large form in the sense of a product-oriented project which is very time consuming and often stretches out over several weeks or months. It demands high motivation and enormous dedication from the participants and can only be realised as an extra-curricular activity. The fact that during the rehearsals and the staging of a play, the participants gain long lasting learning experiences in relation to language, literature and culture along with significant insights contributing to their personal development, has often been documented, more recently for example by Marini/Ryan-Scheutz (2010).

Another large-scale form is the Theatre-in-Education-Project, which is mainly associated with the staging of a play especially created by semi-professional teacher-actors. Ideally, it is based on topics that come up in the foreign language classroom over the course of a school year. Before the staging takes place in the

\footnotetext{
${ }^{9}$ In this context, also note the article 'Drama to go' by Sambanis et al. in this issue.
} 


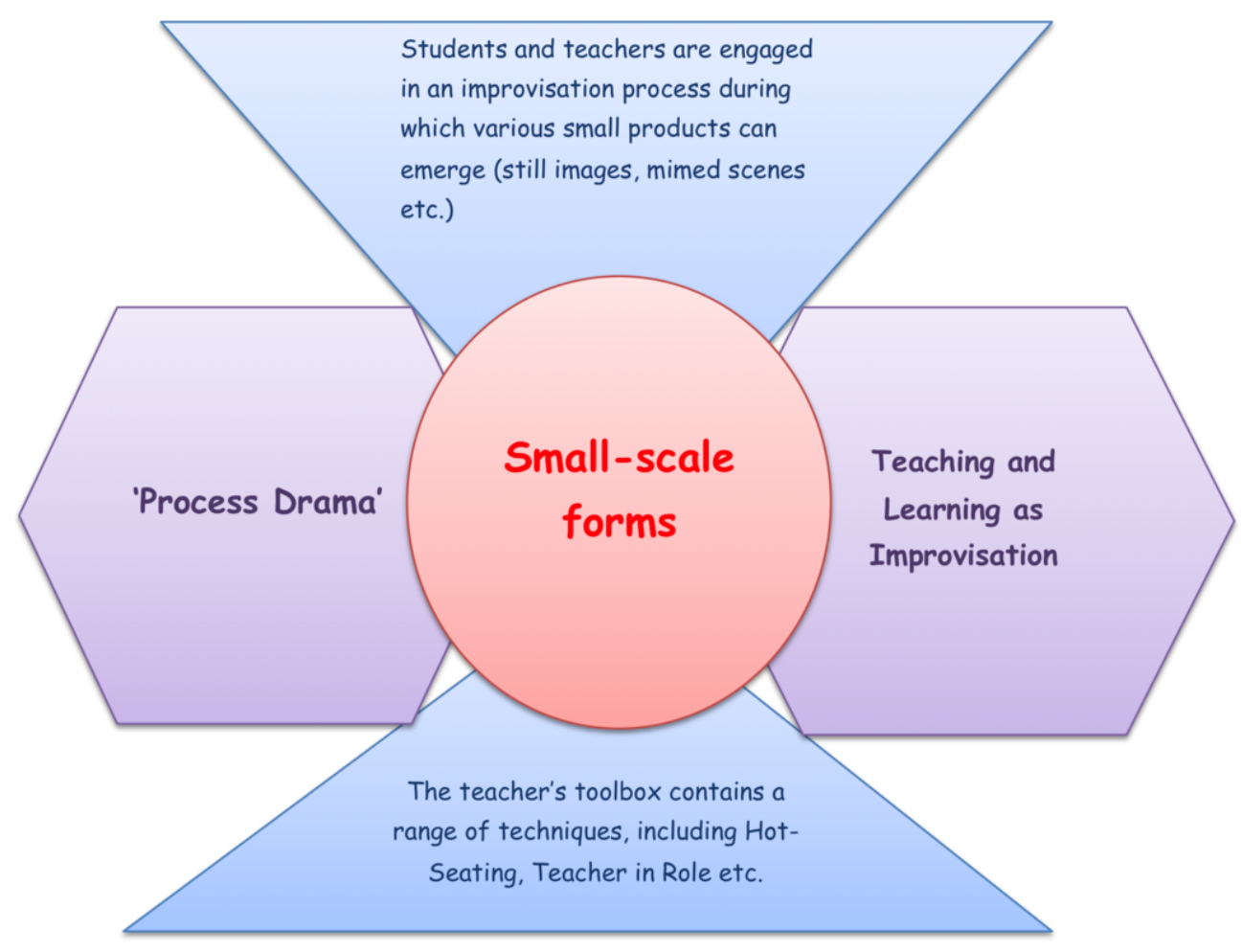

Figure 1: Small-scale forms

school, teachers normally receive specially adapted materials which they can use in order to prepare the students for the special event. The performance in the school, although primarily orientated towards learning, is nevertheless of a quite high aesthetic standard and often constitutes a highly motivating learning experience for the pupils. In addition, meeting with native speakers, dialoguing with the actors after the play and re-enacting some aspects of it under the actors' instructions helps pupils delve deeper into selected dramatic scenes, leaving an indelible impression on them. In 2009, Aita demonstrated, using the example of Austria, the enormous contribution made by Theatre in Education groups over the past decade to the development of the teaching and learning of foreign languages in schools. In the meantime, a great number of theatres in Germany have established drama/theatre pedagogy departments which are responsible for the building of bridges between theatre and school and, together with both teachers and students, are developing and implementing the 'TUSCH Projects' (Theatre and School Projects) (http://www.tusch-berlin. de). In this context, we may note a project for foreign students at Hamburg University. They were introduced to German culture by watching a contemporary German play in the Gorki Theatre in Berlin, and through performative activities set up and led by the 'theatre pedagogues' at the Gorki Theatre (Jogschies/Krohn 2009).

Language camps are a further example of the large-scale form, where, over the course of a two week holiday, language learning activities, theatre-based 


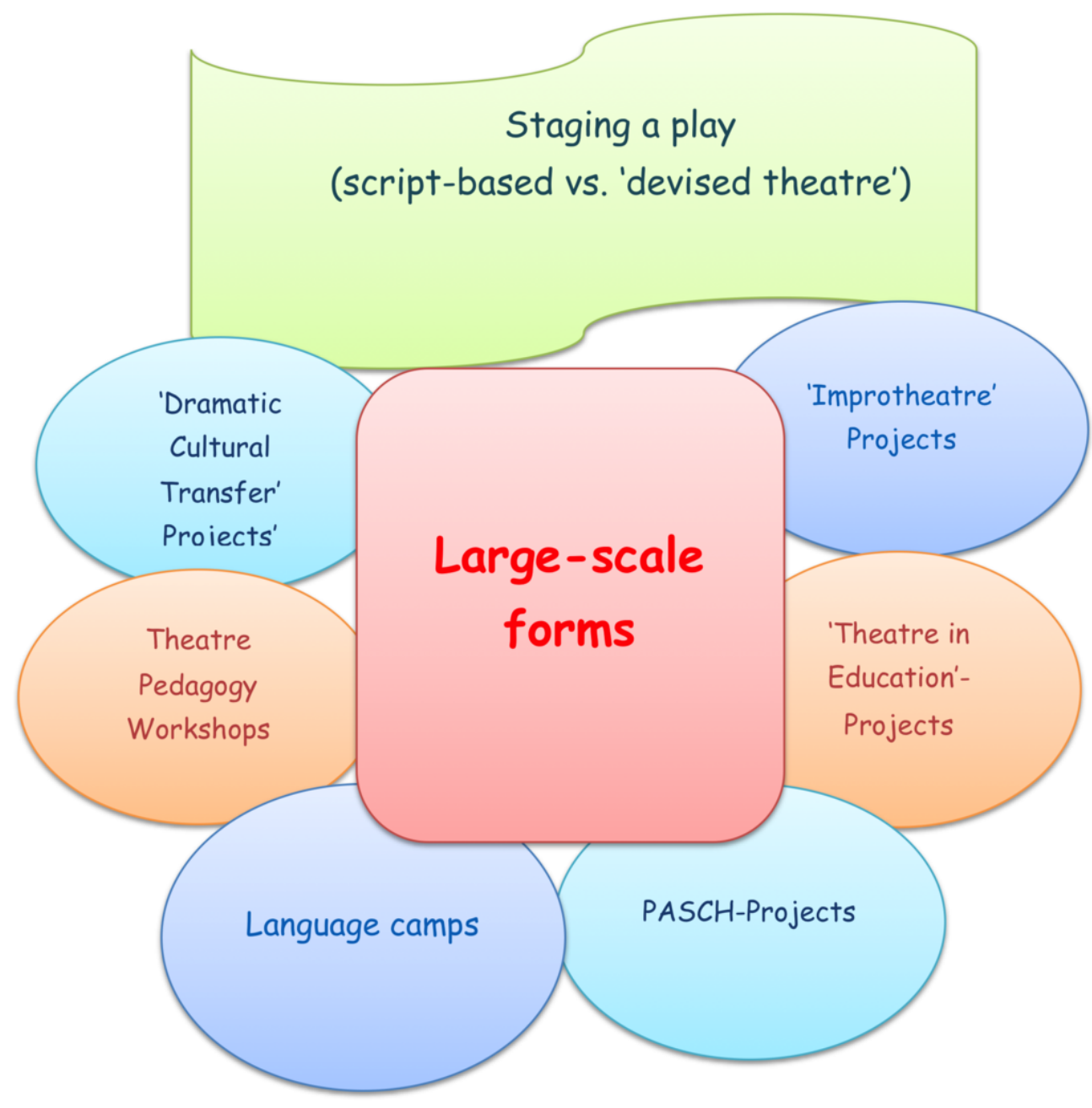

Figure 2: Large-scale forms

performative activities and hobby related activities mingle, and where the multilingualism of the children is explicitly taken into consideration (compare, for example, the description of the Hamburg theatre and language camp model by Sting (2012) and Kinze (2012)).

Also noteworthy are 'PASCH Projects', where collaborating partner schools from different countries cooperate and, for example, under the instructions of theatre pedagogues, work together on a product-oriented theatre project (compare, for example Oelschläger's (2010) description of a student theatre project carried out in cooperation with partner schools of the Goethe Institute in Central Eastern Europe).

'Culture Transfer Projects' work on the basic assumption that foreign language departments commit themselves to function as 'bridge builders' between different cultures by translating and adapting dramatic texts for performance in a specific location and cultural setting. An example of this is the 
project recently undertaken by Boyd and Schewe (2012) at University College Cork in Ireland. The experience of trying out performative approaches to Thomas Hürlimann's play, Das Einsiedler Welttheater (2007), with BA students of Language and Literature and also MA students of Drama and Theatre Studies gave birth to the idea of creating an English language adaptation of the original (German/Swiss German language), entitled Cork's World Theatre. Through the project, Irish audiences were given an insight into German contemporary drama and a specific Swiss model of 'Community Theatre' (For an account of the genesis of the project, see the YouTube film at: http://www . youtube. com/watch?v=sEBX1-1B6Ak).

Even though there have been many practice reports in relation to the aforementioned small- and large-scale forms, there is still a lack of more systematic research into the specific teaching and learning processes linked to these forms, including how performative classroom activities match Common European Framework (CEP) criteria. $^{10}$ What is still needed, following the study mentioned above by Wagner (1998), is a systematic stock-take of research endeavours up to now in the area of 'Drama pedagogy and the teaching and learning of foreign or second languages'. In doing so, special consideration should be given to the contributions of the working group 11 Theatermethoden und Fremdsprachenforschung (Theatre Methods and Foreign Languages Research) within the framework of the $24^{\text {th }}$ Conference of the German Association for foreign language research (see Scenario VI,2,2012).

\section{Towards a Performative Foreign Language Didactics}

The paradigm shift in the aesthetic field from work to process; from the art or literary object to the act, event, happening, action - in a word, to performance, has continued to influence and feed the theoretical discourse in various disciplines, including the foreign language disciplines. In the past, Fremdsprachendidaktik ('Foreign Language Didactics') was almost exclusively considered a scientific discipline. This emerges, for example, in Article 2 of the Statute of the Deutsche Gesellschaft für Fremdsprachenforschung (German Society for Foreign (and Second) Language Research), where, in the description of the purpose of Foreign Language Didactics, the word 'science' or 'scientific' is used thirteen times but the word 'art' or 'artistic' is not even mentioned once. It should be noted, however, that Foreign Language Didactics is increasingly opening itself up to include the aesthetic field, or rather the various arts (theatre, music, visual art, dance, film, performance art). Evidence of this can be found, for example, when looking at pertinent core discussions at conferences in different parts of the world; the Goethe Institute, for example, organised a conference for teachers of German in Bangalore, India, entitled Kunst des Unterrichtens - Unterrichten mit Kunst (The Art of Teaching - Teaching

10 However, in this context, note the perspectives of Schmenk 2009, Bünger 2010, Fonio/Genicot 2011. 
Through Art) in February 2012. Another conference organised by the Centre of Research at the University of Nantes, and took place in September 2012, was called Langues en mouvement: didactique de langues et pratiques artistiques (Languages in Motion). In March 2013, the National Autonomous University of Mexico, the Goethe Institute, the German Academic Exchange Service (DAAD) as well as the Austrian Exchange Service (OEAD), organised a conference in Mexico entitled Ästhetisches Lernen im DaF-Unterricht. Musik - Kunst - Film Theater - Literatur (Aesthetic learning in the German as a foreign language classroom. Music - Art - Film - Theatre - Literature).

Over the course of the past two to three decades drama pedagogy has advanced to become an important reference discipline in Foreign Language Didactics, one which has laid the foundations for the further development of a Performative Fremdsprachendidaktik (Performative Foreign Languages Didactics). ${ }^{11}$ It recognises drama-based teaching and learning not only as a science but also as an art and shares Eisner's (2008) notion that, by taking an artistic approach, unique insights and learning opportunities can be created. Let's take the example of a German as a Foreign Language class, where a text about the situation of an East German border control guard is being discussed; it makes a huge difference whether the text is discussed merely in class or whether a pupil playing the soldier is moving through two rows of pupils who act as his inner voice and whisper, encouraging him to either risk escaping to the West, or discouraging him and telling him to stay where he is. The student adopting the role of the soldier will, no doubt, experience a high degree of inner turmoil as he reacts to the various contradictory voices while he takes a step forward, then perhaps suddenly hesitates, turns back, advances again, etc. This 'embodied experience' will create a deeper understanding of the huge personal dilemma the soldier finds himself in. Here, dramatic art provides a platform for an intensive learning experience for the student and his classmates alike.

It is the intention of a Performative Foreign Language Didactics to avail of the wealth of forms found in the arts for teaching and learning purposes. It is, above and beyond the disciplines usually associated with foreign language teaching and learning (e.g. general pedagogy, first language didactics, psychology, linguistics and literature), actively seeking dialogue and exchange with the arts, in particular with theatre arts and also school/university subjects related to the aesthetic field (including music, visual art, dance, literature, film). In this context, there are no clear-cut lines between science and art, theory and practice.

The goal of foreign language didactics is to create a new approach to teaching and learning, whereby emphasis is placed on forms of aesthetic expression. This means that special attention is given to 'language form' and to the pleasure and even desire to play with words, sentences and expressions. 'Form' also implies the ways in which the body speaks and how sound, word, sentence and movement all interact with each other.

Further discussions about Performative Foreign Language Didactics will, no

\footnotetext{
${ }^{11}$ In this context note, for example, Haack 2010, Schewe 2011.
} 


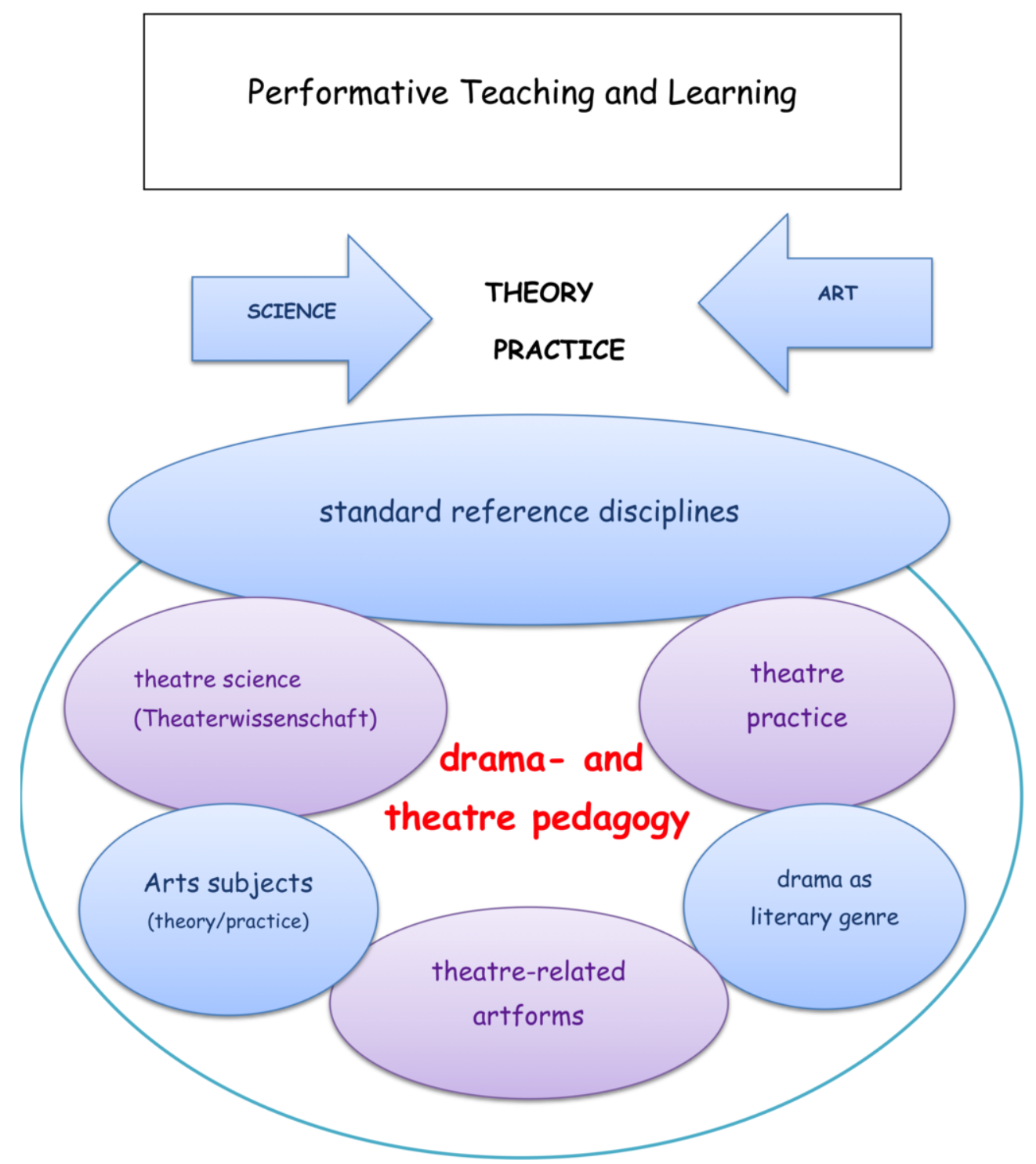

Figure 3: Performative Teaching and Learning

doubt, give new impetus to the initial and in-service training of foreign language teachers. Peter Lutzker's study (2007), which from a multitude of perspectives interestingly highlights teaching as an art and emphasises the effectiveness of drama- and theatre-based methods for teachers, could serve as a good starting point. The same goes for attempts to embed drama-related teaching methods into teacher training programmes (for instance, at the University of Göttingen (Haack 2010 and Haack/Surkamp 2011) and the University of Educational Science, Freiburg (Fleiner 2012)), and, last but not least, for the views of Dunn \& Stinson (2011:630), who focused on what they term 'teacher artistry' and, reflecting on the outcome of their research project with teaching staff in 
Singapore, came to the conclusion that:

When drama learning experiences are planned and implemented by teachers who are concerned with, and aware of, dramatic form and we are able effectively to manage the four roles of actor, director, playwright and teacher, across both the macro and micro levels of planning and implementation, the language outcomes for students are enhanced. (ibid.)

A Performative Foreign Languages Didactics would need to further define what is meant by 'teacher artistry' and how exactly this could be further developed.

The fact that this overview primarily highlights British drama pedagogy as a key discipline of Foreign Language Didactics and does not focus to the same extent on German theatre pedagogy, can be explained by the simple fact that we are dealing with a very recent discipline whose beginnings date back to the 1970s and 1980s (compare survey by Koch 2011).

While over the past two decades the foreign language teaching debate in Germany has been heavily influenced by British drama pedagogy, there are numerous indications that German 'Theaterpädagogik' (theatre pedagogy) is increasingly contributing to research and practice in the area of 'Hochschuldidaktik' (the theory and practice of teaching and learning at third level) (e.g. Wildt/Hentschel/Wildt 2008) as well as Foreign Languages Didactics (e.g. Vecchione-Grüner 2011, Holl 2011). It is therefore proposed that 'performative' be used as an umbrella term to describe (the various culturally-specific) forms of foreign language teaching that derive from the performing arts.

According to Wulff/Zirfass (compare 2007, 11), the perspective of the performative, besides facilitating a more differentiated understanding of 'pedagogical actions', also offers a more complex theory of 'Bildung'. The term 'Bildung' captures the process and the outcome of a transformation which affects both, one's own self as well as one's relationship to others and the world. 'Bildung' therefore signifies how culture and individuality can connect in such a way that it becomes possible to create the conditions which enable a person to relate to others and the world and, thus, ultimately, give the person's self a form.

In Wilhelm Meister's Apprenticeship (1795/96), Johann Wolfgang von Goethe's well-known 'novel of formation' (Bildungsroman), it is the theatre that allows Wilhelm, the eponymous hero, to give his self a form:

Now, this harmonious cultivation of my nature, which has been denied me by birth, is exactly what I most long for. Since leaving thee, I have gained much by voluntary practice: I have laid aside much of my wonted embarrassment, and can bear myself in very tolerable style. My speech and voice I have likewise been attending to; and I may say, without much vanity, that in society I do not cause displeasure. But I will not conceal from thee, that my inclination to become a public person, and to please and influence in a larger circle, is daily growing more insuperable. With this, there is combined my love for poetry and all that is related to it; and the necessity I feel to cultivate my mental faculties and tastes, that so, in this enjoyment henceforth indispensable, I may esteem as good the good 
alone, as beautiful the beautiful alone. Thou seest well, that for me all this is nowhere to be met with except upon the stage; that in this element alone can I effect and cultivate myself according to my wishes. ${ }^{12}$

Over the last two decades, drama pedagogy has helped to lay the foundations for a new teaching and learning culture which accentuates physicality and centres on 'performative experience' (see Schewe, 2011). While the example of Wilhelm Meister might reassure us that we are on the right track, we need to remind ourselves that Goethe offers us a very idealistic perspective. There is, of course, no harm in refueling our own idealism, but we need to give priority, in the years to come, to an increasingly differentiated understanding of the nature and quality of performative experience that can be achieved in foreign language teaching and learning.

\section{Acknowledgments:}

- This article is a translated and slightly adapted version of "Fokus Fachgeschichte: Die Dramapädagogik als Wegbereiterin einer performativen Fremdsprachendidaktik". The original German version will appear in: Carola Surkamp/Wolfgang Hallet (eds.) (2013): Dramendidaktik und Dramapädagogik. Trier: WVT.

I wish to thank the editors and the German publishing company, Wissenschaftlicher Verlag Trier, for giving the permission to publish an English version in SCENARIO.

I am also very grateful to Lorraine O'Leary for the first translation draft, to Lucia Marcello for assisting with the graphic representations and to Stephen Boyd, Mandy Collins, Eucharia Donnery and Mike Fleming for helpful comments and proof-reading the manuscript.

\section{Bibliography}

Ackroyd, Judith (ed.) (2006): Research Methodologies for Drama Education. Stoke on Trent (UK)/Sterling (USA): Trentham.

Aita, Sean (2009): The Theatre in Language Learning (TiLL) Model. Exploring Theatre as Pedagogy in the L2 environment. In: Scenario III, 1, 70-89

Bolton, Gavin (1979): Towards a Theory of Drama in Education. London: Longman

Bolton, Gavin (1984): Drama as Education. An Argument for Placing Drama at the Centre of the Curriculum. Harlow: Longman

Bolton, Gavin (1993): A Brief History of Classroom Drama: British and Other English-speaking Influences. In: Schewe \& Shaw (1993, 25-42)

\footnotetext{
12 From: Johann Wolfgang von Goethe: Wilhelm Meister's Apprenticeship and Travels, Vol. I (of 2), Book V, Chapter 3. Translated by Thomas Carlyle, The Project Gutenberg eBook http://www. gutenberg.org/cache/epub/36483/pg36483.txt - 2.12.2012
} 
Bolton, Gavin (1999): Acting in Classroom Drama. A Critical Analysis. Portland/Maine: Calendar Islands

Bourke, Eoin (1993): Work at the Coalface. An Empirical Approach to Foreign Language Theatre for Students. In: Schewe \& Shaw (1993, 227-248)

Bowell, Pamela \& Brian S. Heap (2001): Planning Process Drama. London: Fulton

Boyd, Stephen \& Manfred Schewe (2012): Welttheater: übersetzen, adaptieren, inszenieren. Thomas Hürlimanns Das Einsiedler Welttheater; nach Calderón de la Barca und in englischsprachiger Fassung: Cork's World Theatre. Berlin: Schibri

Bräuer, Gerd (ed.) (2002): Body and Language. Intercultural Learning through Drama. Westport, CT/London: Ablex

Bryant, Doreen (2012): DaZ und Theater: Der dramapädagogische Ansatz zur Förderung der Bildungssprache. In: Scenario VI, 1, 27-55

Bünger, Ursula (2010): Individualisierung und Fiktionalisierung der Kann-Beschreibungen des Europäischen Referenzrahmens durch Dramapädagogik mit Handyfilmen. In: Scenario IV, 2, 41-62

Cook, Caldwell Henry (1917): The Play Way. An Essay in Educational Method. London: Heinemann

Coggin, Philip A. (1956): Drama and Education. An Historical Survey from Ancient Greece to the Present Day. London: Thames and Hudson

Dockalova, Bara (2011): Loops: A Multi-Purpose Drama Technique for the Language Classroom. In: Scenario V, 1, 66-74

Dunn, Julie \& Madonna Stinson (2011): Not without the Art!! The Importance of Teacher Artistry when Applying Drama as Pedagogy for Additional Language Learning. In: Research in Drama Education: The Journal of Applied Theatre and Performance 16,4, 617-633

Eisner, Elliot W. (2002): The Arts and the Creation of Mind. New Haven/London: Yale UP

Esselborn, Karl (2010): Interkulturelle Literaturvermittlung zwischen didaktischer Theorie und Praxis. München: Iudicium

Even, Susanne (2003): Drama Grammatik. Dramapädagogische Ansätze für den Grammatikunterricht Deutsch als Fremdsprache. München: iudicium

Even, Susanne (2011): Multiple Hotseating. In: Scenario V, 2, 112-113

Federer, Urban (2007): Einsiedler Theatertradition. In: Welttheatergesellschaft Einsiedeln (ed.): Das Einsiedler Welttheater. Nach Calderón von Thomas Hürlimann. Regie: Volker Hesse. Programmbuch. 22. Juni bis 8. September 2007. Zürich: Ammann, 86-93

Finlay-Johnson, Harriet (1911): The Dramatic Method of Teaching. London: Nisbet

Fleiner, Micha (in preparation): Transversale Schnittstellen in der Lehramtsausbildung: Entwicklung eines Konzeptes zum Aufbau 
dramapädagogischer Französischlehrkompetenz im Rahmen künstlerisch-ästhetischer Lehr-Lern-Projekte. PH Freiburg (PhD project)

Fleming, Michael (1997): The Art of Drama Teaching. London: Fulton

Fonio, Fillipo \& Genicot, Geneviève (2011): The Compatibility of Drama Language Teaching and CEFR Objectives. Observations on a Rationale for an Artistic Approach to Foreign Language Teaching at an Academic Level. In: Scenario V, 2, 75-89

Goethe, Johann Wolfgang von (1795/96): Wilhelm Meister's Apprenticeship and Travels, Vol. I (of 2), Book V, Chapter 3. Translated by Thomas Carlyle, The Project Gutenberg eBook -

http: / / www . gutenberg.org/cache/epub/36483/pg36483.txt - 2.12.2012

Haack, Adrian (2010): KünstlerInnen der improvisierten Aufführung. Performative Fremdsprachendidaktik als Teil des Lehramtsstudiums. In: Scenario IV, 1, 35-53

Haack, Adrian \& Carola Surkamp (2011): Theatermachen' inszenieren. Dramapädagogische Methoden in der Lehrerbildung. In: Küppers et al. (2011, 53-67)

Hahn-Michaeli, Brigitte (2011): Wie Nathan der Weise nach Israel kam. Szenische Interpretation eines klassischen deutschen Dramas in einer multikulturellen und multilingualen Lerngruppe. In: Scenario V, 1, 21-39

Hallet, Wolfgang (2010): Performative Kompetenz und Fremdsprachenunterricht. In: Scenario IV, 1, 5-18

Holl, Edda (2011): SPRACH-FLUSS. Theaterübungen für Sprachunterricht und interkulturelles Lernen. Ismaning: Hueber

Hürlimann, Thomas (2007) Das Einsiedler Welttheater. Zürich: Ammann

Jogschies, Bärbel \& Doris Krohn (2009): HEAVEN - theaterpädagogisch vorund nachbereitet. In: Scenario III, 1, 3-16

Johnstone, Keith (1993): Improvisation und Theater. Berlin: Alexander Verlag

Kao, Shin-Mei \& Cecily O'Neill (1998): Words into Worlds. Learning a Second Language through Process Drama. Stanford, Conn: Ablex

Kessler, Benedikt (2008): Interkulturelle Dramapädagogik. Dramatische Arbeit als Vehikel des interkulturellen Lernens im Fremdsprachenunterricht. Frankfurt a.M.: Lang

Kessler, Benedikt \& Almut Küppers (2008): A Shared Mission. Dramapädagogik, interkulturelle Kompetenz und holistisches Fremdsprachenlernen. In: Scenario II, 2, 3-24

Kinze, Julia (2012): Das Hamburger TheaterSprachCamp. Methoden und Ergebnisse der Evaluation. In: Scenario VI, 1, 85-102

Koch, Gerd (2011): Zur Theaterpädagogik in der Bundesrepublik Deutschland. Ein Überblick. In: Scenario V, 1, 76-94

Küppers, Almut, Torben Schmidt \& Maik Walter (eds.) (2011): Inszenierungen im Fremdsprachenunterricht. Grundlagen, Formen, Perspektiven. Braunschweig: Diesterweg 
Kunz, Marcel (2010): Theatralisiert den Literaturunterricht. Unterrichtsmodelle für den Literaturunterricht der Sekundarstufe II. Baltmannsweiler: Schneider

Lutzker, Peter (2007): The Art of Foreign Language Teaching. Improvisation and Drama in Teacher Development and Language Learning. Tübingen: Francke

Mairose-Parovsky, Angelika (1997): Transkulturelles Sprechhandeln. Bild und Spiel in Deutsch als Fremdsprache. Frankfurt a.M.: Lang

Marini-Maio, Nicoletta \& Colleen Ryan-Scheutz (eds.) (2010): Set the Stage. Teaching Italian Through Theater. New Haven/London: Yale UP

Neelands, Jonothan \& Tony Goode (2000): Structuring Drama Work. Cambridge: Cambridge UP

Oelschläger, Birgit (2011): 'Wenn man sieht, dass die Jugendlichen wirklich dabei sind.' Das Schülertheaterprojekt der Partnerschulinitiative in Mittelosteuropa. In: Scenario V, 1, 54-65

O’Neill, Cecily (1995): Drama Worlds. A Framework for Process Drama. New Hampshire: Heinemann

Retzlaff, Steffi (2010): Leben mit der Mauer. Reiner Kunzes „Schießbefehl“. In: Scenario IV, 1, 54-82

Scheller, Ingo (2004): Szenische Interpretation. Seelze-Velber: Kallmayer

Schewe, Manfred (1993): Fremdsprache inszenieren. Zur Fundierung einer dramapädagogischen Lehr- und Lernpraxis. Oldenburg: Didaktisches Zentrum [available online: http://cora.ucc.ie/handle/10468/561 12.06.2013]

Schewe, Manfred \& Peter Shaw (1993): Towards Drama as a Method in the Foreign Language Classroom. Frankfurt a.M.: Lang

Schewe, Manfred (2011): Die Welt auch im fremdsprachlichen Unterricht immer wieder neu verzaubern. Plädoyer für eine performative Lehr- und Lernkultur! In: Küppers et al. (2011, 20-31)

Schewe, Manfred \& Heinz Wilms (1995): Texte lesen und inszenieren. Alfred Andersch: Sansibar oder der letzte Grund. München: Klett Edition Deutsch

Schmenk, Barbara (2004): Drama in the Margins? The Common European Framework of Reference and its Implications for Drama Pedagogy in the Foreign Language Classroom. In: GFL - German as a Foreign Language 1, 7-23

Shakespeare, William (2006): As You Like It. Edited by Juliet Dusinberre. London: Arden Shakespeare

Slade, Peter (1954): Child Drama. London: London UP

Sting, Wolfgang (2012): Performance und Theater als anderes Sprechen. In: Scenario VI, 1, 54-63

Stinson, Madonna \& Joe Winston (2011): Drama and Second Language Learning. In: Research in Drama Education 16,4, 479-644

Tselikas, Elektra I (1999): Dramapädagogik im Sprachunterricht. Zürich: Orell Füssli 
Wagner, Betty Jane (1979): Dorothy Heathcote. Drama as a Learning Medium. London: Hutchinson

Wagner, Betty Jane (1998): Educational Drama and Language Arts. What Research Shows. Portsmouth, NH: Heinemann

Ward, Winifred (1930): Creative Dramatics. New York: Appleton

Way, Brian (1967): Development Through Drama. Harlow: Longman

Wulff, Christoph \& Zirfas, Jörg (eds) (2007): Pädagogik des Performativen: Theorien, Methoden, Perspektiven. Weinheim: Beltz

Vecchione-Grüner, Sabina \& Sigrid Unterstab. (2011): Die Welt - ein (virtuelles?) Lebensdorf. In: Scenario V, 2, 48-58

Wildt, Beatrix, Ingrid Hentschel \& Johannes Wildt (eds.) (2008): Theater in der Lehre. Verfahren, Konzepte, Vorschläge. Berlin/Zürich: LIT 